\title{
An Impact of Banking Activities of Private Commercial Islamic Bank to Economic Development in Bangladesh: A Case Study on First Security Islami Bank Limited (FSIBL)
}

\author{
Md. Nazirul Islam Sarker', Md. Harun Or Rashid ${ }^{2}$ \\ ${ }^{1}$ School of Business, Bangladesh Open University, Gazipur, Bangladesh \\ ${ }^{2}$ Department of Management, University of Dhaka, Dhaka, Bangladesh
}

Email address:

naziru12012@gmail.com (Md. N. I.Sarker)

\section{To cite this article:}

Md. Nazirul Islam Sarker, Md. Harun Or Rashid. An Impact of Banking Activities of Private Commercial Islamic Bank to Economic Development in Bangladesh: A Case Study on First Security Islami Bank Limited (FSIBL). Journal of Investment and Management. Vol. 4, No. 5, 2015, pp. 264-272.doi: 10.11648/j.jim.20150405.28

\begin{abstract}
Banks are the most important parts of the financial system of any country. Specially, developing country like Bangladesh, proper banking system is very important and essential to play a vital role, because capital market system in Bangladesh is not advanced like other country's capital market. The study analyses published texts, articles, websites and annual report of this bank through a content analysis. Key findings of this study manifest the contribution of this bank in different areas of economic development in Bangladesh like generating employment, earning foreign remittance, strengthening rural economy, promoting ecology and green banking, boosting industrialization, developing the SMEs, assisting in foreign trade (import-export) and developing the housing sector etc. This study also identifies FSIBL's significant contribution to the national exchequer. This paper contributes to the field of economic development of Bangladesh and the role of FSIBL behind it and fills the gap of literature in this specific area. The study suggests that Islamic banking has a great impact on the economic development in Bangladesh.
\end{abstract}

Keywords: Islamic Banking, Shariah, Bangladesh, Economic Development

\section{Background of the Study}

Banking sector of the world is contributed in the present global economy. To establish a strong banking sector it is required to have good study in banking operations. Today's Economic policy is concerned to obtain the optimum economic condition in a country's economy. Banking sector and banking activities are playing a vital and important role to achieve that optimum goal of the economy. The successful running of banking business depends upon effective banks. As a new commercial bank FSIBL has a huge responsibility to ensure efficient and effective banking operation all over the Bangladesh in a sound manner with other Banks as a competitor.

Banking sector is indispensable in a modern age and modern society.It always plays a vital role to the economic development of a country. In modern age of science and technology the banking sector all over the world has been undergoing a lot of changes due to deregulation, technological innovation and globalization. But Bangladeshi banking sector is lagging to keep pace with the other countries to adapt the changes. Basically bank take deposits from the customers against some interest payments and lend the money to the borrowers with a different interest rate and time period. To ensure safety of the depositors fund there are various types of credit facility. Also bank must hold adequate fund to meet the daily needs of the clients. The First Security Islami Bank Ltd (FSIBL) is a $3^{\text {rd }}$ (Third) generation is doing its business with a view to serve the best to the customers and clients all over the country.

Kosmidou and Zopounidis (2008) evaluated and rated the performance and efficiency of the commercial and cooperative banks in Greece for the period 2003-2004. They found in this study that commercial banks are becoming more competitive and maximizing their profits by increasing their accounts, attracting more customers and improving their financial indices. But in case of the cooperative banks, it has been found that, some are enjoying considerably increased profits and market shares while financial indices have been found to be deteriorating for others. 
Moreover, the services of private commercial banks in this country are now better than before. As a result, the clients are rushing to the private banks. Consequently, the private commercial banks are constantly growing in different branches, creating employment opportunities, increasing deposit, loan disbursement, net income and earnings per share over a period of time. As competition is rising in the banking industry due to the emergence of new banks in the market, it has become important to evaluate the performance of every private commercial bank. (Chowdhury and Islam, 2007).

Islamic banks are facing immense national and global challenges, when it is making financial transactions, trading or as a working partner. However, if appropriate laws and regulations persist in a society or at the global level, Islamic banks can manifest its performance appropriately. Two prolific writers of Islamic finance, Ahmad and Hassan remark that Islamic banks in Bangladesh came into existence with certain objectives, in line with the philosophy of Islamic economics that imply a direct and specific responsibility on their part to play an effective role in the socioeconomic development of the country. (Ahman, auf. and hassan, k.,2001)

It has been found that these depositors and entrepreneurs have got the opportunity to practice Shariahbased banking and fulfil their religious obligation. Alam describes the reasons behind the success of IBBL and narrated that in addition of Shariahcompliance, senior officials of the bank also keep a regular contact with customers and bank managers frequently visit them in their places of business. Referring to the chief of the Investment Department of the IBBL, Alam commented that though this bank initially faced some challenges, the situation is getting better than before. (Alam, M.N., 2000)

Referring to the existence of Islamic banking amid conventional banking system and economy, Sarkar expresses that Islamic banking system can provide efficient banking services if they are supported with appropriate banking laws, and regulations (Sarker, A.A.,1999)

Hassan views that the successful launching and operation of Islamic banks in Bangladesh has established that banking without interest is feasible. He also observes that Islamic banks have brought together many new depositors and entrepreneurs under the banking system. (Hasan, K., 1999).

Though there are a number of definitions exist, it is generally understood that economic development refers to the standard of living of the citizens improved through alleviating poverty and increased productivity. Also Kifle, Olukoshi, Wohlgemuth support this idea that there is a strong relationship between poverty alleviation and economic development. (Kifle, H., Olukoshi, A., Wohlgemuth, 1., 1997)

Banks and financial institutions are contributing in the economic development of Bangladesh through exploring different lucrative economic segments in the form of investment and lending. Banks of our country play roles from conventional and Islamic perspective. Islamic Banks are operating based on Islamic sariah\& principles that does not support interest based banking where as conventional banks are in favor of interest and conventional rules \& regulation. So, it is necessary to determine how much extent of impact of Islamic Banking activities of a commercial bank on economic development in Bangladesh.

\section{Objective of the Study}

- To determine the extent of impact of Islamic Banking Activities of FSIBLon economic development in Bangladesh.

- To determine the major problems in banking sector.

- To recommend for the better and more efficient strategy to solve the problems in banking sector.

\section{Methodology}

Both the primary and secondary sources have been used. We have used some quantitative or factual information too. Simply, the information sources from which we have collected the information that are needed in the report can be divided into two categories. These are

Primary sources\&Secondary sources.

Primary Sources:Face to face conversation and Personal interview.

Secondary Sources:Annual Reports and Web Sites of FSIBL.

For determining the extent of Impact of Islamic banking on economic development of Bangladesh, we have used data in successive five years from 2005 to 2009.

\section{Findings}

Growth\& Development of the First Security Islami Bank Limited:

The growth \& development ofthe First Security Islami Bankcan be observed by the following indicators which are included capital, paid up capital, branches, statutory reserve, employees, import, export, remittance, assets, investment \& advances, profit before and after tax and deposit etc. and these are described below

\section{Physical Indicators:}

Table 1.The Capital of FSIBL for successive five years from 2005 to 2009.

\begin{tabular}{ll}
\hline & Tk. in Million \\
\hline Year & Total Capital \\
\hline 2005 & 911.94 \\
2006 & $1,147.28$ \\
2007 & $1,347.91$ \\
2008 & $2,862.19$ \\
2009 & $3,379.03$ \\
\hline
\end{tabular}

Source: Annual Report of FSIBL-2009

In the year 2005, the capital of the First Security Islami Bank Ltd was Tk. 911.94 million and in 2006, it was Tk.1147.28 million, thus by increasing their capital it stands Tk.1347.91 million, Tk. 2862.19 million and Tk. 
3379.03 millionin respectively for the year of 2007, 2008 and 2009. So, it reflects the First Security Islami Bank as one of the growing company in the banking industry of Bangladesh and this situation is graphically discovered in below;

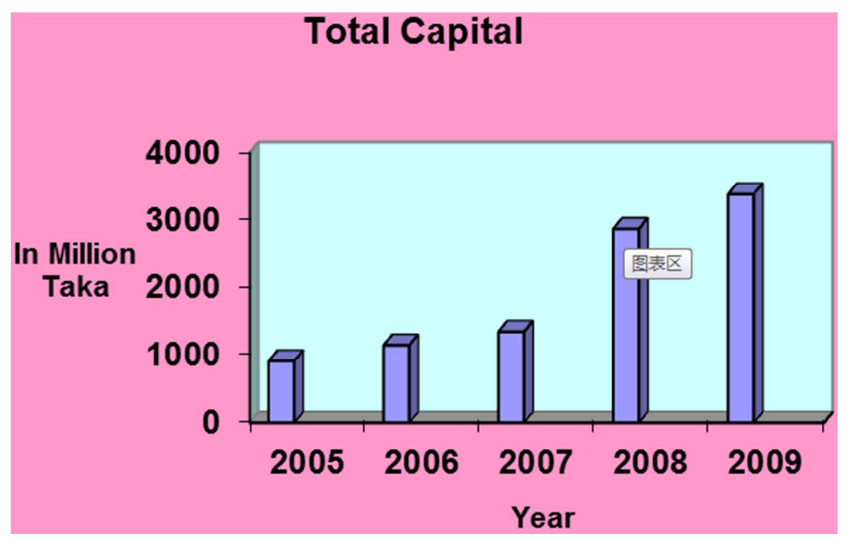

Source: Annual Report of FSIBL-2009

Figure 1. Showing the capital of FSIBL from 2005 to 2009.

Table 2. The Paid Up Capital of FSIBL for successive five years from 2005 to 2009.

\begin{tabular}{ll}
\hline & Tk. In Million \\
\hline Year & Paid Up Capital \\
\hline 2005 & 600 \\
2006 & 900 \\
2007 & 1000 \\
2008 & 2300 \\
2009 & 2300 \\
\hline
\end{tabular}

Source: Annual Report of FSIBL-2009

In the year 2005, the paid-up capital of the First Security Islami Bank Ltd was Tk. 600 million and in 2006, it was Tk.900 million, thus by increasing their capital it stands Tk.1000 million, Tk. 2300 million and Tk. 2300 millionin respectively for the year of 2007, 2008 and 2009. So, it reflects the First Security Islami Bank as one of the growing company in the banking industry of Bangladesh although the increasing rate of paid-up capital remain same in 2008 \& 2009 and this situation is graphically discovered in below.

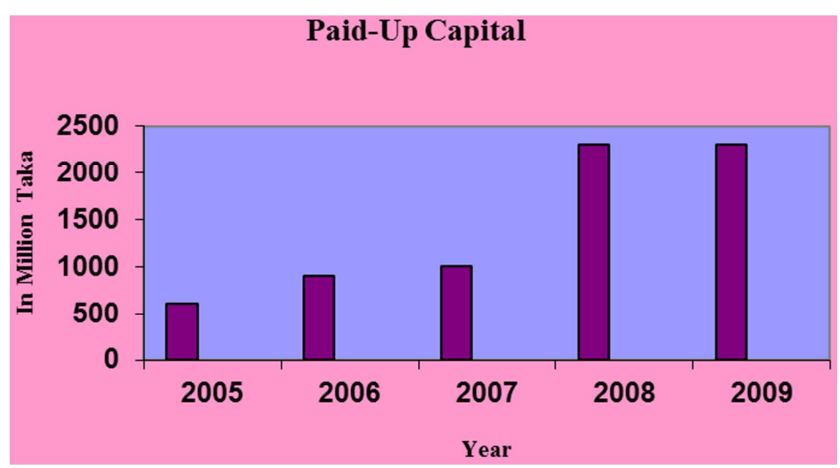

Source: Annual Report of FSIBL-2009

Figure 2. Showing the Paid Up Capital of FSIBL from 2005 to 2009.
Table 3. The Number of Branches of FSIBL for successive five years from 2005 to 2009.

\begin{tabular}{ll}
\hline Year & Branches \\
\hline 2005 & 12 \\
2006 & 15 \\
2007 & 20 \\
2008 & 29 \\
2009 & 52 \\
\hline
\end{tabular}

Source: Annual Report of FSIBL-2009

The number of branches of the First Security Islami Bank is increasing by time. It is observed that in the year of 2005, the number ofbranches was only 12, but in 2007 it became as 20 and thus FSIBL increased the branches to 52 till $31^{\text {st }}$ December, 2009. So that, now the number of branches is 59 and two new branches are going to open as soon as possible. This situation is graphically discovered in below

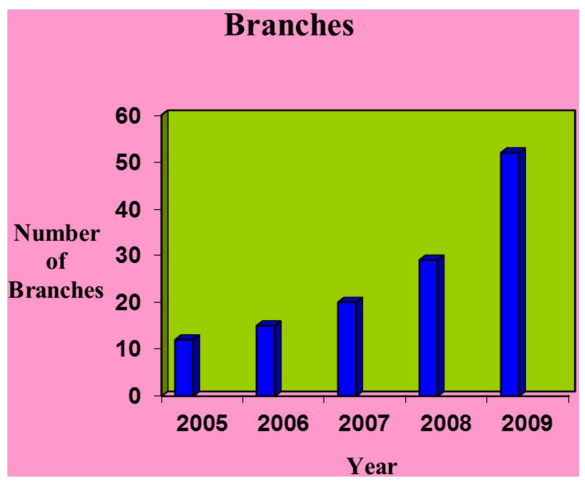

Source: Annual Report of FSIBL-2009

Figure 3. Showing the number of branches of FSIBL from 2005 to 2009.

Table 4. The growth of Statutory Reserve of FSIBL for successive five years from 2005 to 2009.

\begin{tabular}{ll}
\hline & Tk. in Million \\
\hline Year & Statutory Reserve \\
\hline 2005 & 84.45 \\
2006 & 84.45 \\
2007 & 96.16 \\
2008 & 134.08 \\
2009 & 263.44 \\
\hline
\end{tabular}

Source: Annual Report of FSIBL-2009

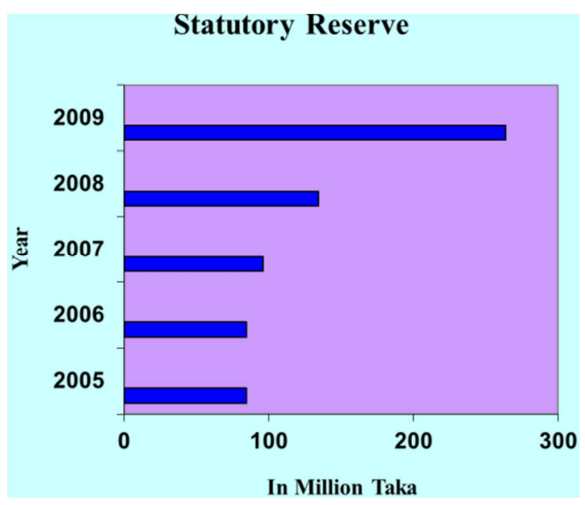

Source: Annual Report of FSIBL-2009

Figure 4. Showing the growth of Statutory Reserve of FSIBL from 2005 to 2009. 
The statutory reserve of the First Security Islami Bank was Tk.84.45 milliomin 2005and it remained same figure in theyear of 2006, it increased in 2007 as well as 2008 in succession Tk.96.16 million and Tk. 134.08 million. Thus, statutory reserve of FSIBL became Tk. 263.44 million in the year 2009 with a positive situation and it is showed below with a graph

Table 5. The growth of employment generation of FSIBL for successive five years from 2005 to 2009.

\begin{tabular}{ll}
\hline Year & Employees \\
\hline 2005 & 423 \\
2006 & 318 \\
2007 & 412 \\
2008 & 483 \\
2009 & 775 \\
\hline
\end{tabular}

Source: Annual Report of FSIBL-2009

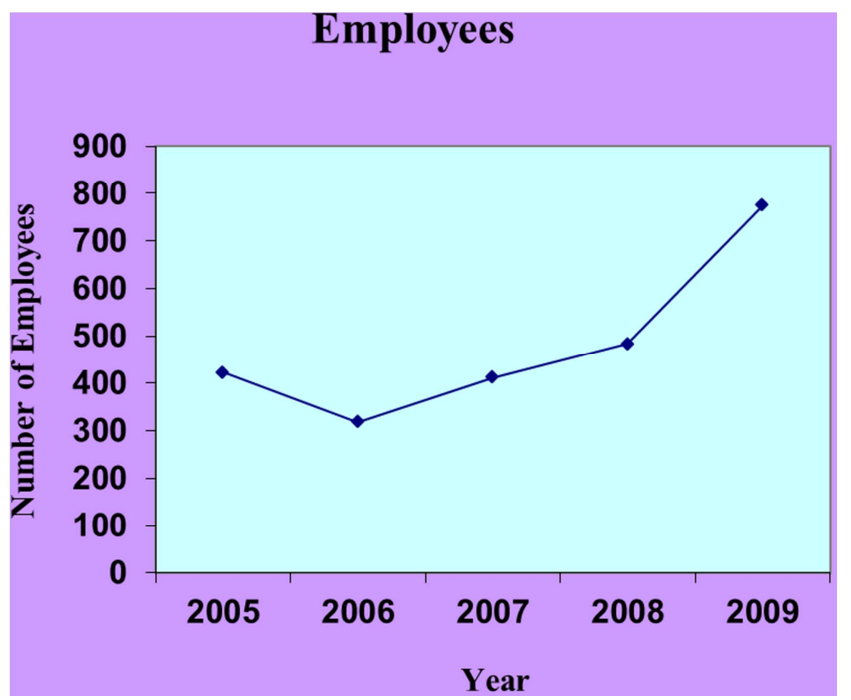

Source: Annual Report of FSIBL-2009

Figure 5. Showing the growth of employment generation of FSIBL from 2005 to 2009.

By observing above data and graph it can be said that in the year 2005 the number of employees in FSIBL was 423, but it decreased its employees in 2006 so it became 318 in number. Again, in 2007 FSIBL started to take employees so that the number of employees became at 412 and in the year 2008 it became 483, thus the number of employees in FSIBL was 775 which confirmed in the annual report of 2009 .

Table 6. The growth of FSIBL in case of Import Business for successive five years from 2005 to 2009.

\begin{tabular}{ll}
\hline & Tk. in Million \\
\hline Year & Import \\
\hline 2005 & 6605.4 \\
2006 & 7153 \\
2007 & 14344.44 \\
2008 & 9287 \\
2009 & 16101.17 \\
\hline
\end{tabular}

Source: Annual Report of FSIBL-2009

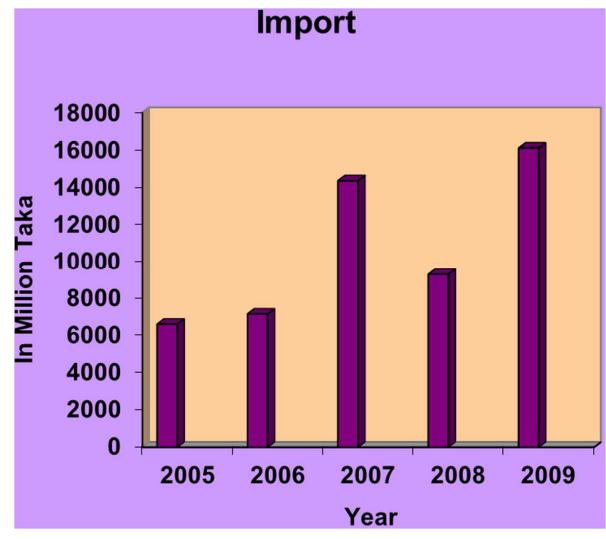

Source: Annual Report of FSIBL-2009

Figure 6. Showing the growth in case of Import Businessof FSIBL from 2005 to 2009

By observing above data and graph it can be said that in the year 2005, FSIBL's importing amount is Tk. 6605.04 million as financial figure, Tk.7153 million in 2006 and Tk. 14344.44 million in 2007. But in the year of 2008 it decreased and downed at the figure Tk. 9287 million. In 2009, the financial figure of import became at Tk. 16101.17 million.

Table 7. The growth of FSIBL in case of Export Business for successive five years from 2005 to 2009.

\begin{tabular}{ll}
\hline & Tk. in Million \\
\hline Year & Export \\
\hline 2005 & $2,856.40$ \\
2006 & $2,960.00$ \\
2007 & $3,648.40$ \\
2008 & $4,145.00$ \\
2009 & $3,549.00$ \\
\hline
\end{tabular}

Source: Annual Report of FSIBL-2009

By analyzing above data, we can say that, from the year 2005 to 2008, the export situation of First Security Islami Bank is good enough though in the year 2009 it decreased slightly. It increased to $\mathrm{Tk}$. 4,145.00 million from Tk. $2,856.40$ million. The financial figure of export of FSIBL is Tk. 3,549.00 million confirmed in the annual report of 2009.

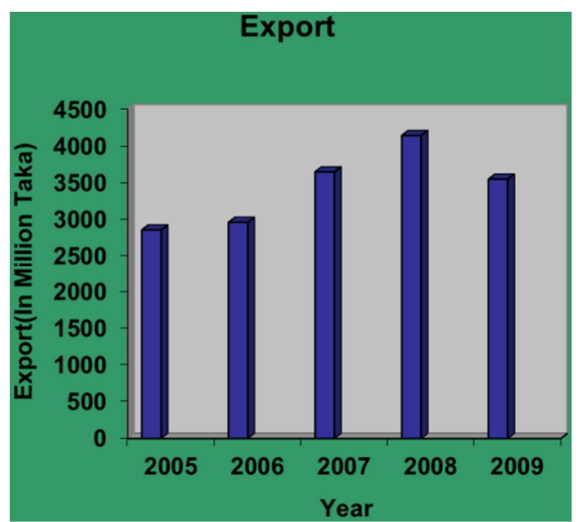

Source: Annual Report of FSIBL-2009

Figure 7. Showing the growth of Export Business of FSIBL from 2005 to 2009. 
Table 8. The growth of FSIBL in case of Foreign Remittance for successive five years from 2005 to 2009.

\begin{tabular}{ll}
\hline & Tk. in Million \\
\hline Year & Remittance \\
\hline 2005 & 62.21 \\
2006 & 48.44 \\
2007 & 330 \\
2008 & 558.84 \\
2009 & 558.75 \\
\hline
\end{tabular}

Source: Annual Report of FSIBL-2009

By analyzing above data, we can say that, from the year 2005 to 2008, the situation of remittance was improved from the year 2005 to 2008. In 2005 the financial figure of remittance was Tk. 62.21 million which became Tk. 558.84 million in the year of 2008. In 2009, the financial figure of remittance remained same figure as Tk. 558.75 million according to the annual report-2009 of FSIBL.

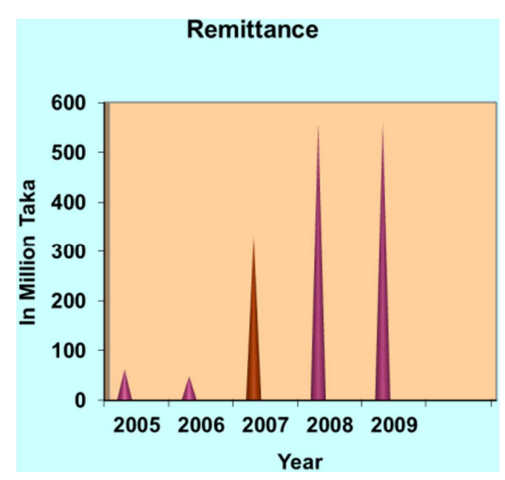

Source: Annual Report of FSIBL-2009

Figure 8. Showing the growth of FSIBLin case of Foreign Remittance from 2005 to 2009.

Table 9. The growth of FSIBL in case of Asset for successive five years from 2005 to 2009

\begin{tabular}{ll}
\hline & Tk. in Million \\
\hline Year & Assets \\
\hline 2005 & $20,260.33$ \\
2006 & $20,448.66$ \\
2007 & $26,942.00$ \\
2008 & $31,239.00$ \\
2009 & $47,978.55$ \\
\hline
\end{tabular}

Source: Annual Report of FSIBL-2009

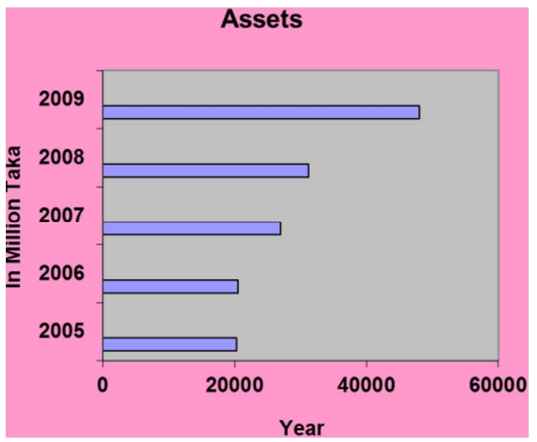

Source: Annual Report of FSIBL-2009

Figure 9. Showing the growth in case of Foreign Remittance of FSIBL from 2005 to 2009.
The asset of the First Security Islami Bank was Tk. 20,260.33 milliomin 2005andin theyear of 2006, it increased to Tk. 20,4448.66 million, it increased in 2007 also. In 2008, it became Tk. 31,239 million. Thus, asset of FSIBL became at Tk. 47,978.55 millionin 2009 with a positive situation and it is showed below with a graph.

Table 10. The growth of FSIBL in case of Investments \& Advances for successive five years from 2005 to 2009.

\begin{tabular}{ll}
\hline & Tk. in Million \\
\hline Year & Investments \& Advances \\
\hline 2005 & 10722.32 \\
2006 & 13646.38 \\
2007 & 18616.22 \\
2008 & 25094.65 \\
2009 & 38725.87 \\
\hline
\end{tabular}

Source: Annual Report of FSIBL-2009

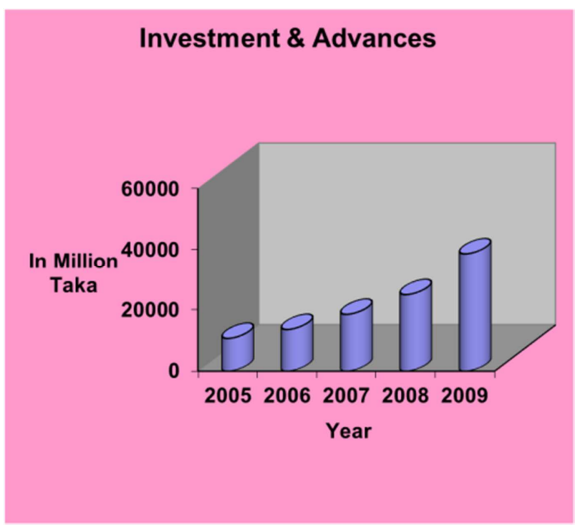

Source: Annual Report of FSIBL-2009

Figure 10. Showing the growth in case of Investments \& Advances of FSIBL from 2005 to 2009.

By observing above data and graph it can be said that in the year 2005, FSIBL's investments \& advances amount is Tk. 10722.32 million as financial figure, Tk13646.38 million in 2006 and Tk. 18616.22 million in 2007, Tk.25094.65million in the year of 2008. In 2009, the financial figure of import became at Tk. 38725.87 million. So we can include the FSIBL as one of the growing company in the banking industry of Bangladesh.

Table 11. The growth of FSIBL in case of Profit for successive five years from 2005 to 2009.

\begin{tabular}{lll}
\hline & Tk. in Million & Tk. in Million \\
\hline Year & Profit Before Tax & Profit After Tax \\
\hline 2005 & 17.98 & 9.88 \\
2006 & -132.22 & -117.24 \\
2007 & 58.53 & 30.63 \\
2008 & 189.6 & 104.28 \\
2009 & 650.83 & 330.83 \\
\hline
\end{tabular}

Source: Annual Report of FSIBL-2009

From the above data we can conclude that, profit before tax and after tax of the FSIBLare in respectively Tk. 17.98 million and Tk. 9.88 million in 2005. But in the year 2006, this amount is in off situation. Again, in 2007, 2008 it 
increased as Tk. 58.53 million \& Tk. 90.63 million. At last, in the year 2009, profit before tax of the FSIBL is Tk.650.83 million and after tax is Tk. 330.83 million.

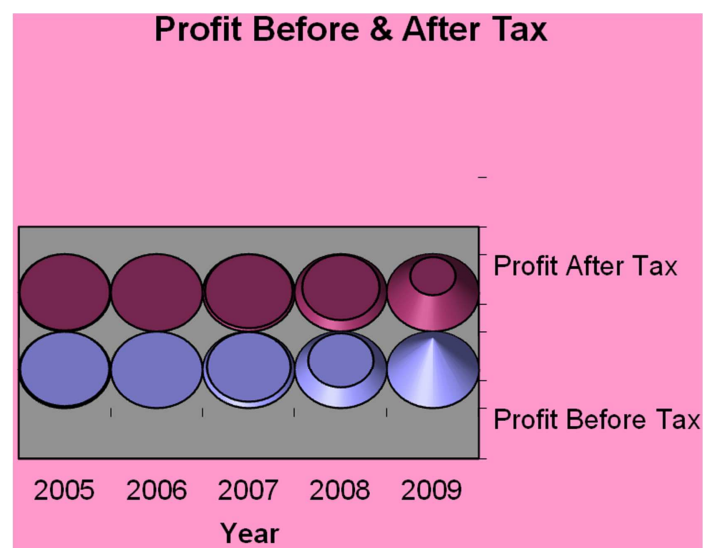

Source: Annual Report of FSIBL-2009

Figure 11. Showing the growth in case of Profit of FSIBL from 2005 to 2009.

Table 12. The growth of FSIBL in case of Deposit for successive five years from 2005 to 2009.

\begin{tabular}{ll}
\hline & Tk. in Million \\
\hline Year & Deposit \\
\hline 2005 & 14012.17 \\
2006 & 17592 \\
2007 & 23504.04 \\
2008 & 25854.54 \\
2009 & 42423.09 \\
\hline
\end{tabular}

Source: Annual Report of FSIBL-2009

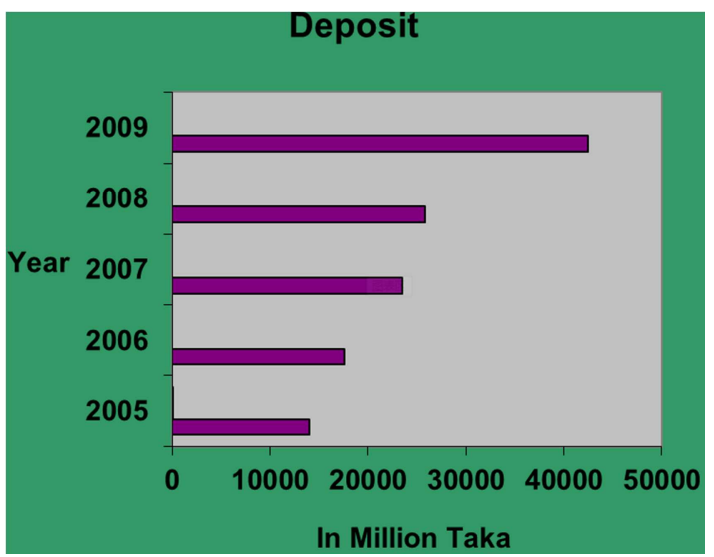

Source: Annual Report of FSIBL-2009

Figure 12. Showing the growth in case of Deposit of FSIBL from 2005 to 2009.

From the above data and graph of the FSIBL, we can see, the deposit amount of FSIBL in 2005 was Tk.14012.17 million, in 2006 the amount of deposit was Tk. 17592 million as financial situation of deposit increased in2007 also and it reached at Tk.23504.04 million. Thus the deposit of FSIBL increased day by day and as a result it reached at the amount of Tk. 42423.09 million. So, as a growing company in the banking industry of Bangladesh is in better performance.
Table 13. Financial Highlights of First Security Islami Bank Limited.

\begin{tabular}{|c|c|c|}
\hline & In Taka & \\
\hline Particulars & 2009 & 2008 \\
\hline Paid-up Capital & $2,300,000,000$ & $2,300,000,000$ \\
\hline Total Capital Fund & 3379.03 & $2,862,198,083$ \\
\hline Capital Surplus / (Deficit & $267,692,742$ & $1126,543,146$ \\
\hline Total Assets & $47,978,552,952$ & $31,239,393,418$ \\
\hline Total Deposits & $42,423,092,722$ & $25,854,541,500$ \\
\hline Total Investment & $38,725,874,774$ & $25,094,658,077$ \\
\hline $\begin{array}{l}\text { Total Contingent Liabilities and } \\
\text { Commitments }\end{array}$ & $5,971,673,066$ & $4,611,289,577$ \\
\hline Investment Deposit Ratio (in \%) & $91.28 \%$ & $96.39 \%$ \\
\hline Percentage of Classified Loans & & \\
\hline $\begin{array}{l}\text { Against Total Loans and Advances } \\
\text { (in \%) }\end{array}$ & $2.14 \%$ & $4.20 \%$ \\
\hline Profit Before Tax and Provision & $750,837,749$ & $189,603,753$ \\
\hline Amount of Classified Investment & $830,515,000$ & $1,053,412,705$ \\
\hline $\begin{array}{l}\text { Provision Kept Against Classified } \\
\text { Investment }\end{array}$ & $507,694,000$ & $597,694,000$ \\
\hline Provision Surplus / (Deficit) & $53,834,571$ & $31,818,406$ \\
\hline Cost of Fund & $9.28 \%$ & $11.37 \%$ \\
\hline Profit Earning Assets & $41,371,529,125$ & $28,529,063,421$ \\
\hline Non-Profitt Earning Assets & $6,607,023,827$ & $2,710,329,997$ \\
\hline $\begin{array}{l}\text { Return On Investment in Shares \& } \\
\text { Securities (ROI)(in \%) }\end{array}$ & $2.79 \%$ & $15.18 \%$ \\
\hline Return on Assets (ROA) (in \%) & $1.56 \%$ & $0.61 \%$ \\
\hline $\begin{array}{l}\text { Income From Investment in Shares } \\
\& \text { Securities }\end{array}$ & $53,510,527$ & $202,345,834$ \\
\hline Earning Per Share & 14.21. & 7.35 \\
\hline Net Income Per Share & 14.21 & 7.35 \\
\hline Price Earning Ratio & 15.39 & 23.74 \\
\hline
\end{tabular}

Sources: Annual Report of FSIBL-2009

\section{Principles of Islamic Banking}

Islamic banking has the same purpose as conventional banking except that it operates in accordance with the rules of Shariah, known as Fiqh al-Muamalat. The basic principle of Islamic banking is the sharing of profit and loss and the prohibition of riba. Amongst the common Islamic concepts used in Islamic banking are profit sharing (Mudharabah), safekeeping (Wadiah), joint venture (Musharakah), cost plus (Murabahah).

In an Islamic mortgage transaction, instead of loaning the buyer money to purchase the item, a bank might buy the item itself from the seller, and re-sell it to the buyer at a profit, while allowing the buyer to pay the bank in installments. However, the fact that it is profit cannot be made explicit and therefore there are no additional penalties for late payment. In order to protect itself against default, the bank asks for strict collateral. The goods or land is registered to the name of the buyer from the start of the transaction. This arrangement is called Murabaha. Another approach is EIjarawaEIqtina, which is similar to real estate leasing. Islamic banks handle loans for vehicles in a similar way.

An innovative approach applied by some banks for home loans, called Musharaka al-Mutanaqisa, allows for a floating rate in the form of rental. The bank and borrower forms a partnership entity, both providing capital at an agreed percentage to purchase the property. The partnership entity then rent out the property to the borrower and charges rent. 
The bank and the borrower will then share the proceed from this rent based on the current equity share of the partnership. At the same time, the borrower in the partnership entity also buys the bank's share on the property at agreed installments until the full equity is transferred to the borrower and the partnership is ended. If default occurs, both the bank and the borrower receive the proceeds from an auction based on the current equity. This method allows for floating rates according to current market rate such as the BLR (base lending rate), especially in a dual-banking system like in Malaysia.

There are several other approaches used in business deals. Islamic banks lend their money to companies by issuing floating rate interest loans.

The floating rate of interest is pegged to the company's individual rate of return. Thus the bank's profit on the loan is equal to a certain percentage of the company's profits. Once the principal amount of the loan is repaid, the profit-sharing arrangement is concluded. This practice is called Musharaka. Further, Mudaraba is venture capital funding of an entrepreneur who provides labor while financing is provided by the bank so that both profit and risk are shared. Such participatory arrangements between capital and labor reflect the Islamic view that the borrower must not bear all the risk/cost of a failure, resulting in a balanced distribution of income and not allowing lender to monopolize the economy. And finally, Islamic banking is restricted to Islamically acceptable deals, which exclude those involving alcohol, pork, gambling, etc. Thus ethical investing is the only acceptable form of investment, and moral purchasing is encouraged. In theory, Islamic banking is an example of fullreserve banking, with banks achieving a 100\% reserve ratio.

However, in practice, this is not the case, and no examples of 100 per cent reserve banking are observed. Islamic banks have grown recently in the Muslim world but are a very small share of the global banking system. Micro-lending institutions founded by Muslims, notably Grameen Bank, use conventional lending practices and are popular in some Muslim nations, especially Bangladesh, but some do not consider them true Islamic banking. However, Muhammad Yunus, the founder of Grameen Bank and microfinance banking, and other supporters of microfinance, argue that the lack of collateral and lack of excessive interest in microlending is consistent with the Islamic prohibition of usury.

\section{ImpactIslamic Banking on Economic Development of Bangladesh}

Due to global economic recession, time is very much challenging and uncertain. Specially, this calamity become acute with eventual collapse of some major banking institution and massive dips in stock market indices across the globe. As a result, developing economy like Bangladesh economy deteriorated rapidly.

Bangladesh represents a underdeveloped financial system which leads a slow economic growth. According to the international monetary fund, Bangladesh ranked as the $48^{\text {th }}$ largest economy in the world in 2009, with a GDP of US\$256 billion. Although Bangladeshi economy is based on agriculture, more than half of the GDP is belongs to the service sector such as transport, financial institution, real estate education, public administration, health, social and personal service. From the financial institution, banking industry is the most essential.

The banking industry of Bangladesh is now highly competitive and challenging sector rather than previous period of time. Basically banking sector is involved with financial system. To have a healthy and vibrant economy it needs a financial system that moves funds from people who save people who have strong productive investment opportunities. And we know that, a country's economic development means development the economy of a country which concern with trade, industry and wealth of the country.

Despite sluggish economic senario, the FSIBL passed successfully with the help of their efficient and prudent workforce. Thus FSIBL has been able to close the balance sheet with an enormous pre-tax profit of Tk.750 million with an excellent growth rate of $300 \%$ while the whole financial sector faced a slowdown. Banking institution can create an impacton the economy through its general activities like deposit collection, giving loan, invest in different economic sector such as agriculture, garments, house building etc. export and remittance business.

There is a link between financial system and economy. Without financial sector an economic system can not draw its growth. Banks are the most financial intermediaries and FSIBL is not different from them. General banking activities are like the flow of bloods of any bank which are practiced and operated to keep a bank alive.

So, FSIBL is also having its own general activities like other banks. A/C opening, closing, loan and investment, ATM banking, locker service, SMSbanking etc.

In the society there live different people and they have different demands and needs. FSIBL is ready to serve them as their choice by offering various types of $\mathrm{A} / \mathrm{C}$ such as $\mathrm{Al}$ wadiah A/C, Mudarabah Special Notice A/C, Mudarabah Savings A/C, Mudarabah Monthly Savings Scheme. FSIBL offers different types loan and opportunity to invest and shares risk with the customers.

Although, at first FSIBL was started as usual commercial bank in 1999, but after several yearit was changed to a Islamic Bank and its principles developed based on Islamic Shariah. There are 90\% muslim people in Bangladesh, they have islamic mind and culture. So that, FSIBL is giving opportunity the people to invest thus by collecting deposit from them and investing from different sector such as invest in industry developing and thus bank earn profits and share with it's customer and shareholders, if failed then also be shared between them.

ATM banking of FSIBL is not fully independent. It does an agreement with Dutch Bangla Bank Limited. So thus the customer of FSIBL who want to hold ATM card they have to give service charge yearly Tk.300 and it also a way of 
earning and adding in GDP of the country.

Table 14. Economic Sector wise Investments.

\begin{tabular}{|c|c|c|}
\hline & \multicolumn{2}{|c|}{ Amount in Tk. } \\
\hline & 31.12 .2009 & 31.12.2008 \\
\hline \multicolumn{3}{|l|}{ Agriculture: } \\
\hline Fishing & 92400000 & 90453000 \\
\hline Tea & - & - \\
\hline Others & 145700000 & 72825000 \\
\hline \multicolumn{3}{|l|}{ Textiles and Readymade Garments: } \\
\hline Garments & 356500000 & 223124000 \\
\hline Readymade Garments- Export & 413000000 & 379514000 \\
\hline Textile and Textile Products- Import & 1198600000 & 345914000 \\
\hline Others-Export & 455000000 & 348426000 \\
\hline Others-Import & 2877300000 & 1227259000 \\
\hline Medicine-Import & 83300000 & 56874000 \\
\hline Chemical-Import & 15500000 & 10431000 \\
\hline Contractor Finance & 2353200000 & 2057744000 \\
\hline Transport & 79600000 & 31394000 \\
\hline Bricks & 10100000 & 16890000 \\
\hline Cold Storage & 69800000 & 43473000 \\
\hline Steel \& Engineering & 55000000 & 50748000 \\
\hline \multicolumn{3}{|l|}{ Internal Trade Finance: } \\
\hline Whole Sale Trading & 5943300000 & 4581529000 \\
\hline Retail Trading & 4886700000 & 1367004000 \\
\hline Others & 4559000000 & 4723643000 \\
\hline \multicolumn{3}{|l|}{ House Building: } \\
\hline Commercial & 2925300000 & 387069000 \\
\hline Staff & 61100000 & 53025000 \\
\hline \multicolumn{3}{|l|}{ Special Program: } \\
\hline $\begin{array}{l}\text { Consumer Finance \& Hire Purchase } \\
\text { Scheme }\end{array}$ & 67000000 & 54475000 \\
\hline Others & 12078474774 & 8972844077 \\
\hline
\end{tabular}

Source: Annual Report of FSIBL-2009

Like other successful bank FSIBL also has SMS banking so that customer can know about the status of their $\mathrm{A} / \mathrm{C}$ and make their transaction, as always other types of services of the bank. So that, it is saving more time consuming and is able to serve many customers in a little time and get opportunity to concentrate in other objectives.

FSIBL is one of the $3^{\text {rd }}$ generation bank. Despite of this it increases it's branches within a short period of time. That's why at present FSIBL have 62 branches. Along with this, it recruits skilled and experienced people as employee and arrange training program for them who are not skilled enough. Thus it decreases the unemployment problem of the country which is helping indirectly to enlarging the growth rate of GDP. FSIBL is giving services through Ahsania Mission to the root level people in easier way and low cost. It also keeps valuable products in safe by providing locker service. In this service, people are getting safety. On the other hand, bank earns profits by making service charge from the customers and obviously by giving better service.

FSIBL is one of the Islamicbank of Bangladesh, which is playing an important role in banking sector of Bangladesh through its different activities. Like other different banks, FSIBL also invest in different economic sector such as agriculture, textile \& readymade garments, house building and other such special programs having great impact on the economy. It is observed through the following data comparing with the previous period which revealed in the last annual report 2009. That is presenting a positive situation is given below.

On the other side, we can relate import and export of a country with its economical consideration. So, thus, it is observed the import, export and remittance business of the FSIBL is improved.

\subsection{Import Business}

Import trade finance by FSIBL rose to Tk. 1610.17 crore in reporting year compared with Tk. 928.70 crore in 2008. Large LCs are opened mainly for importing rice, wheat, edible oil, fertilizer, capital machinery, fabrics and accessories.

\subsection{Export Business}

FSIBL successfully handled export documents of Tk. 3549 million during the reporting year compared with Tk. 4145 million in the year 2008. Readymade garments, frozen foods, fish, tanned leather, handicraft etc.

\subsection{Remittance Services}

From the last report we know that, foreign remittance of the bank stood at Tk. 558.7 million as of December 31,2009 as against Tk. 585.8 million in 2008. So thatthrough the Foreign Exchange service of FSIBLthe people of Bangladesh can well served the bank has taken initiatives to make remittance arrangements with some leading exchange houses at abroad.

More people of Bangladesh who are working out of country, for them, FSIBL has attached with 501 branches of 8 banks through ELDORADO. This bank has its own exchange house in Canada.

\section{Corporate Social Responsibilities}

Although FSIBL is a corporate citizen of Bangladesh, it has also some social responsibilities. Thus First Security Islami Bank is aware of its corporate social responsibilities it supports to the development of community through promotion of culture, sports, educational program and disaster and treatment aid of the distressed people. The bank actively participates for promotion of the sports, religious events and cultural activities. Recently bank has donated Tk. 25 lacs to the Aila fund, Tk. 28 lacs to the Bangladesh Association of Banks for BDR carnage and Tk. 50 lacs to the Port City League (PCL). The FSIBL is also introducing FSIBL foundation very soon.

Overall the other activities FSIBL has different contribution also such as

- FSIBL donated Tk 50, 00,000/- for Liberation War Museum

- FSIBL donated Tk 30, 00,000/- to Prime Minister's Relief \& Welfare Fund

- Tk.2000000/- is given as assistance for family members of the martyred Army Officers killed in BDR 
carnage by FSIBL

- To mitigate the sufferings of Aila victims, First Security Islami Bank Limited has donated Tk 10,00,000/- only to Prime Minister's Relief Fund.

- First Security Islami Bank Limited with the assistance of Bankers Forum organized an eye camp for the orphans of DhakaCity.

- As a part of Corporate Social Responsibility, First Security Islami Bank Limited has donated an ambulance to BaitusSharaf ShahJabberiaHospital.

By considering the above information we can make a conclusion that FSIBL is one of the first growing bank which has a impact on developing the economic condition of Bangladesh so it is doing well in foreign exchange service, export \& import Business, economic sector wise investments as well as having corporate social responsibilities.

\section{Conclusion}

FSIBL is one of the fastest growing and best performing banks in Bangladesh. Because of its excellent teamwork among the top management, staff, borrowers, depositors and other stakeholders as well as outstanding banking performance, this bank has secured a very strong position in Bangladesh banking sector. FSIBL has invested in a wide range of areas that not only reduced the risk of investment, but also providing services to a large number of Bangladeshis in home and abroad. This study has portrayed clear a picture of FSIBL's role in the economic development of Bangladesh. If this trend remains continued, FSIBL's contribution will make significant impact on the social and environmental issues in the near future in addition to the economic betterment of the country.

Islamic Economy is required to executed real Islamic banking practice; Bangladesh economy does not cover real practice of Islamic banking although $90 \%$ people of Bangladesh are Muslim in religious status.

Profit Loss Sharing based Banking does not have the chance to bankruptcy of one party but it must be compiled properly.

Investment system of First Security Islami Bank Limited has highly time consuming from the borrower perspective to hamper their operation. There is no proper use of media \& other means.

\section{Recommendations}

- The need for regulation and uniform supervisory of Islamic Banks.

- Issues of risk management and guidelines on risk weight of assets.

- Capital adequacy, liquidity management and issues of controlling of the asset side of Islamic banks.

- Issues in profitability and good governance.

- The necessitate of adoption of new financial methods to Islamic banks.

\section{References}

[1] Ahman, Auf. and K. Hassan, (2001), 'Regulation and Performance of Islamic Banking in Bangladesh', Thunderbird International Business Review, vol. 49, no. 2, pp. 251- 277.

[2] Alam, M.N. 2000. 'Islamic Banking in Bangladesh: A Case Study of IBBL; International Journal of Islamic Financial Services, vol. 1, no. 4.

[3] Chowdhury, H.A. and M.S. Islam. 2007. "Interest Rate Sensitivity of Loans and Advances: A Comparative Study between Nationalized Commercial Banks and specialized Banks,"ASA University Review, vol. 1, pp. 86-97.

[4] Hasan, K. 1999. Islamic Banking in Theory and Practice: The Experience of Bangladesh, Managerial Finance, vol. 25, no. pp. 60-113.

[5] Kifle, H., Olukoshi, A. and L. Wohlgemuth.1997. A New Partnership for African Development: Issues and Parameters, Stockholm: Gotab.

[6] Kosmidou, K.and C. Zopounidis. 2008. "Measurement of Bank Performance in Greece," South-Eastern Europe Journal of Economics, vol. 1, pp. 79-95,.

[7] Sarkar, A.A. (1999), 'Islamic Banking in Bangladesh: Performance, Problems \& Prospects', International Journal of Islamic Financial Services, vol.1, no. 3. 